\title{
Exploration and Practice of the Application-oriented Talent Training Model of the Integration between Industry and Education under the Background of Emerging Engineering Education
}

\author{
Hengyi Yuan, Yi Li* \\ College of Mechanical Engineering, Jilin Engineering Normal University, Changchun, Jilin, 130052, China \\ Supported by JiLin Association For Higher Education (JGJX2020D360)
}

\begin{abstract}
How to train high-quality computer professionals is a key issue facing the computer major under the background of emerging engineering education, and it is also the key to the development of computer majors. This article is based on the idea of emerging engineering education construction, industry needs, and strengthens the integration between industry and education, highlighting Students' main body status, exploring teaching models suitable for application-oriented talent training.
\end{abstract}

Keywords: Emerging Engineering Education Background; Applied Type; Talent Training Model; Integration between Industry and Education

The rapid development of the times has brought us into the emerging engineering education era. The demand for talents in the society has shown a diversified trend. For the training of talents, we should focus on transforming to the application-oriented aspect. It takes great pains to hire talents. These talents not only have a solid theoretical foundation, but also can provide technical guidance in the actual production process, and correctly operate, debug and maintain equipment. Under the background of emerging engineering education, combining the current social needs to cultivate application-oriented talents is the key to its transformation, and it is also the fundamental prerequisite for students' entrepreneurship and employment. Facing the tide of the times, it is necessary to carry out curriculum construction, teaching systems and training models. Reform and optimization can truly realize the cultivation of applied talents.

\section{1. "Interdisciplinary" comprehensive course construction}

The implementation of investigation discipline education can make up for the shortcomings of university professional education to some extent, and it is the expansion of the theoretical knowledge of current college students. Regarding the construction of interdisciplinary courses, we must first optimize the interdisciplinary cooperation mode within the school to realize the cooperation and exchanges between different disciplines and different departments. Through the addition of interdisciplinary professional courses, students' understanding of other disciplines and professions should be expanded to form A diversified curriculum system can also form an intersecting scientific research team to conduct academic discussions and subject competitions, promote the true integration of different subjects, and provide motivation for students' innovative development. Secondly, it is possible to integrate school-enterprise resources by setting up off-campus corporate courses, and to build a training base for corporate employees, with corporate engineers to teach, and to conduct professional knowledge of students to achieve the integrated development of teaching and training.

\section{2. "Integration between industry and education" practice teaching system}

Copyright $\odot 2020$ Hengyi Yuan et al.

doi: $10.18282 /$ le.v9i7.1520

This is an open-access article distributed under the terms of the Creative Commons Attribution Non-Commercial License

(http://creativecommons.org/licenses/by-nc/4.0/), which permits unrestricted non-commercial use, distribution, and reproduction in any medium, provided the original work is properly cited. 
Under the background of emerging engineering education, it is necessary to adjust the teaching mode from the perspective of the enterprise. In order to meet the needs of the enterprise, it is necessary to continuously improve the practical ability of students, and carry out practical teaching on the basis of the overall design of all aspects of practical teaching, and adopt innovative methods. Means, optimize the teaching mode, promote mutual support and coordination between practical courses and theoretical course systems. In school-enterprise cooperation, it is necessary to intensify cooperation and give full play to the benchmarking effect and leading and demonstrative role of the integration of industry and education. On the one hand, it is possible to strengthen the strength of teachers by building a dual-teacher team structure and provide conditions for students' practical ability training. The training of students' practical ability provides conditions. On the other hand, effective measures are taken to improve the comprehensive ability of teachers, create a composite teacher team, change the role of teachers in traditional classrooms, and form a dual-teacher dualability mixed teaching team. Contribute educational value in a place where diversified production and education are integrated.

\section{3. "Innovation and entrepreneurship" talent training model}

Talent is the future of the country. The sustainable development of society and the industry requires continuous construction by talents with creative thinking. This also requires universities to attach importance to the cultivation of students' creative thinking, which is also an important criterion for measuring the level of university and professional teaching. . Especially in the context of emerging engineering education, more emphasis is placed on innovation and entrepreneurship education in colleges and universities, which raises the requirements for college students' practical ability, and highlights the importance of cultivating college students' innovative abilities. This also requires colleges and universities to innovate in teaching and realize it in professional teaching. The integration of theory and practice continuously optimizes teaching content to enable students to have higher professional comprehensive capabilities and form a training model for entrepreneurial and innovative talents.

The entrepreneurial and innovative talent training model emphasizes the improvement of students' practical ability. In order to have a better teaching foundation, universities must increase investment, clarify responsibilities, detailed guidance, and scientific evaluation. First of all, we should strengthen the docking of school-enterprise human resources and form a school-enterprise collaborative scientific research system. Both schools and enterprises work together to build innovation factories and corporate laboratories to provide students with practical opportunities. At the same time, with the development needs of the enterprise as the core, professional courses, practical courses and graduation directions are designed specifically. In teaching, the effect of practical teaching can be improved through the student project responsibility system, and the enterprise project research team can be formed for specific projects, so that students can truly participate in project management, and the student responsibility system can stimulate students' passion for practice, and at the same time, the professional ability of students And develop problem-solving skills. In the teaching process, a double-tutor system should be implemented throughout the teaching process, and a teaching team composed of enterprise engineers and professional teachers will make it easier for students to teach and manage. Secondly, integrate into the entrepreneurial mechanism of college students, mobilize the resources of enterprises, schools, and the government, and make full use of the innovation and entrepreneurship park platform to enable students to have the most powerful conditions for entrepreneurship. Through innovation and entrepreneurship training programs, school-enterprise cooperation projects, and makerspace programs, we provide the most powerful support for student entrepreneurship. Driven by the integration of industry and education, we will establish the concept of entrepreneurship as employment for students, and establish professional application-oriented talents Platform, which should have functions such as entrepreneurship training, guidance, service, practice, incubation, and typical demonstration. Career planners should be incorporated into the teaching staff to help students form a correct view of entrepreneurship, and rich entrepreneurial experience should be transmitted to students to increase the probability of successful entrepreneurship for college students. Finally, in order to respond to the society's demand for applied talents, the internship mode of college students should be diversified and innovated, so that college students can truly penetrate the enterprise and the front line during the internship, thereby improving the employment qualification of college students. 


\section{Concluding remarks}

In the context of emerging engineering education, in order to adapt to the development of the times, it should be based on the integration between industry and education, and comprehensive talents, so as to cultivate applicationoriented talents. This requires education to fully integrate the resources of the government, enterprises, and schools, and work together to build a training model for applied talents, so as to deliver high-quality talents for social and economic development.

\section{References}

1. Zhang Na. Research on the mode of training innovative talents with the integration of production and education under the background of new engineering[J]. Computer Times, 2019, (7): 54-55, 58.

2. Shao Defu, Li Chunjiang, Ma Xiaojun. Research on the Cultivation Mode of Innovation and Entrepreneurship Ability of New Engineering Talents in Local Universities[J]. Science and Technology Entrepreneurship Monthly, 2017, 30(19): 62-64.

3. Wang Shukun, Wang Jinlong, Li Xueguang. A preliminary study on the training model of applied talents in local universities under the background of new engineering disciplines[J]. University Education, 2019, (10): 20-22. 